\title{
TRANSMISIONES DE PRECIOS EN EL SECTOR LÁCTEO: EL ANÁLISIS DEL COMPORTAMIENTO DE LOS PRECIOS DE EXPORTACIÓN Y EL RECIBIDO POR LOS PRODUCTORES*
}

\author{
Rossini, G.R. ${ }^{1 ;}$ Vicentín, J. ${ }^{\text {; }}$ García ARAnCibia, R. ${ }^{1}$ \& Coronel, M. ${ }^{1}$
}

\begin{abstract}
RESUMEN
La transmisión de precios en la cadena láctea es de especial interés para los productores, debido a la presencia de posibles asimetrías. El objetivo del trabajo es examinar los movimientos de precios y la posible existencia de asimetrías entre el precio al productor y el precio de los principales productos exportados. Para ello, se utilizan los modelos TAR (Threshold Cointegration) y M-TAR (Momentum Threshold Cointegration), para analizar la trasmisión de precios con datos mensuales de precios al productory el precio promedio ponderado por su volumen de los productos exportados. Los resultados muestran que las empresas exportadoras pasan más rápido los aumentos de precios que las bajas y que dicho traspaso no es instantáneo sino que lleva un período de dos meses aproximadamente.
\end{abstract}

Palabras Claves: Sector lácteo, Transmisión de precios, Modelos de cointegracióin no lineales.

\section{SUMMARY}

\section{Price transmission in the dairy sector. The analysis of export and producer prices.}

Price transmission in the dairy chain has a particular interest to producers, due to the presence of possible asymmetries. The objective of this study is to examine the price movements and the possible existence of asymmetries between the producer price and the price of the main export products. To do this, we use the TAR models (Threshold Cointegration) and M-TAR (Threshold Cointegration momentum) to analyze the data transmission rates with monthly producer price and the average price weighted by volume of product exported. The results show that exporting producer price respond faster to increase than to decrease in exporting prices, but it takes a period of two months to complete the process.

Key words: dairy sector, price transmission, cointegration threshold model.

\footnotetext{
* Trabajo realizado dentro del marco de los Proyectos PICT 2571-

1.- Facultad de Ciencias Económicas (UNL). Moreno 2557. (3000) Santa Fe. Tel.: (0342) 4585610, int 165. email: grossini@fce.unl.edu.ar

Manuscrito recibido el 10 de octubre de 20013 y aceptado para su publicación el 27 de marzo de 2014.
} 